\title{
PRIVATE AND PRIVATISED HIGHER EDUCATIONAL INSTITUTIONS IN JORDAN
}

\author{
MUHAMMAD RAJI ZUGHOUL
}

\begin{abstract}
Jordan is a country that has prided itself on being a source of trained manpower and which has actively participated in building infrastructures in some neighbouring oil-producing countries. Over the past decade, it has witnessed an unprecedented increase in the establishment of private universities and higher educational institutions. From a country where university education was a monopoly of the state, Jordan has been recently transformed into a haven of financial investment of the private sector in higher education. Twelve fullfledged universities have been established and accredited so far and several other applications for permits for the establishment of more universities are being considered. This paper aims at a descriptive survey of the establishment and growth of private higher education in Jordan. It also aims to provide a critical analysis of the major challenges associated with the privatisation of education, as well as an evaluation of the Jordanian experience in meeting the educational needs of the country and some neighbouring countries, responding to the aspirations of the young and maintaining the required standards for the training, preparation and education of the incoming students. The paper also raises a number of questions that have a bearing on many sensitive issues related to the efficiency of education, commercialisation of education, profiteering, ideology development, and inefficient responses to creativity. Private higher education in Jordan is an innovative trend, but it is an experience worth evaluating. The paper concludes with implications and recommendations.
\end{abstract}

\section{Introduction}

$\mathcal{I}$ ordan has witnessed giant strides in the establishment, growth and expansion of higher educational institutions, first at the level of 2-3 year Institutes, then at the level of the four-year university granting the first degree or undergraduate diploma. Two major reasons lie behind these strides. First is the strong drive in the country towards 'modernisation', 'development', 'progress' or - in a wider sense - 'catching up' with the western standards of living in which education and higher education have been perceived as instrumental since they are a gate for the technological and information revolutions of the modern age. It is also assumed 
that education provides solutions for challenging problems. The second reason is the fact that Jordan prides itself on being a source of trained manpower, skilled human resources which it 'exports' to neighboring oil rich countries and other Arab countries.

Before addressing the topic of this paper, namely private and privatised higher education, it pays to have a glance at the development of higher education in Jordan. In both its Intermediate degree (2-3 years after high school) and in its first degree (4 years after high school) modes. It is worth noting that these 2-3 year Institutes - mostly Teachers' Training Institutes - all became Community Colleges after the decision of The Ministry of Higher Education in 1979.

\section{Institutes and Community Colleges}

The first two year Institute was established in the country in 1952 and it was a Teachers' Training Institute in Amman. Similar other institutes were established in the country to meet the high demand for trained teachers. Nine such colleges sponsored by the Ministry of Education and later by the Ministry of Higher Education were established by 1982, two technical institutes and one hotel management training institute were also established by the Ministry to raise the number of these institutes to twelve. Other Ministries and Governmental Departments in Jordan felt the need to have Institutes of their own to provide the trained manpower needed to work for these Ministries in different parts of the country. Sixteen such colleges were established for the Ministries of Health (nursing Colleges, professional allied health services), Social Affairs (Institute for Cooperation, College of Social Services), Islamic Waqf (College of Islamic Sciences), and the Department of Statistics (Statistical Training Center), the Department of Communications (College of Wired and Wireless Communications), the Royal Medical Services (Princess Mona Nursing College), the Aviation Authority (Royal Aviation Academy), the Royal Geographic Center (College of the Royal Geographic Center), the Central Bank (Institute of Banking Studies). The United Nations' Refugees and Works Agency (UNRWA) established two colleges between the years 1960 and 1971 for the training of the Palestinian refugees living in Jordan. This brings the number of these official and semi-official colleges to 30 (12 Ministry of Education and Higher education, 12 other Ministries and Government Departments, 2 UNRWA). Twenty two similar colleges were established by the private sector in different parts in the country (all for profit, all in major Jordanian cities and mostly in Amman, and established by individuals, families and companies) bringing the total number of colleges to 52 in addition to 14 colleges in the West Bank which was occupied by Israel in 1967. 
Jordan kept its pre-1967 supervisory role of the education sector till the signing of disengagement treaty between the East Bank and the West Bank in the year 1988.

The Community Colleges developed extremely rich and varied programmemes that cover the needs of the different sectors of Jordanian society. These have included eight major programmes with a range of specialisations within each. These are the Academic, the Educational, Engineering, Social Work, Finance and Business, Paramedical professions, Agriculture, Hotel Industry and Fine Arts programmes. Enrollment in these colleges has gone up dramatically to peak in 1990/91 to the figure of 40777 and to drop to half that figure in later years after the spread of private university education which partly replaced community level education.

\section{Official (public) universities}

Jordan has not had a long history of university education. Generally speaking, Jordanian students used to go to other Arab countries for their studies, with Syria, Egypt and Iraq absorbing the largest numbers. I will list the universities in Jordan in their order of establishment.

1. The first Jordanian university - the University of Jordan - was established in the form of a College of Arts and only in the early 1970s did the University of Jordan start to take shape as a full academic institution having the outlay for all the faculties offering most of the traditional specialties offered by other universities.

2. As the University of Jordan took shape in the early 1970s, the second major university, Yarmouk University was established in Irbid with the underlying thinking of being much less traditional stressing the Sciences, Engineering, Economics and Business and Languages. It started teaching in 1976. Yarmouk grew into an academically outstanding institution in both teaching and research because of an open-minded administration, a very active scholarship programme which contributed to the training of a good number of Jordanians in some of the best American universities.

3. A third university was established in M'uta (Karak) in 1984, and this offered military education and training beside the traditional academic training.

4. The Jordan University of Science and Technology (JUST) was constructed near a free industrial zone in the northern part of the country with a view to facilitating the transfer of technology and employing it in the development of the country (cf. JUST 1996). 
5. A fifth university is Aal Al-Bayt University (University of the Kinsmen or Relatives of the Prophet - Prophet Muhammad PBUH), established in Mafraq in order to provide Islamic Shari'a education to Muslim students from NonArabic speaking Islamic states. It started teaching in 1994.

6. The Jordanian University is the Hashemite University in Zarka, the second most important city in Jordan. It was established to respond to the needs of the students in Zarka, and it started teaching in 1994.

7. Balka Applied University was founded in 1997 to oversee the operations of the Community Colleges and Technical Institutes.

8. In addition to these seven universities, there are two 3-year colleges that have been changed into 4-year colleges and given university status. The first of these is what was previously the Amman University College for Applied Engineering, which was established in 1989.

9. The ninth university embraces what was previously the College of Preaching and the Foundations of Religion. This university is directly supervised by the Ministry of Islamic Waqf, Islamic Affairs and Holy Places. It is the only university supervised by an authority outside the Ministry of Higher Education.

These universities offer Academic specialisations in almost all fields of knowledge. The great majority of these departments and academic specialisations are duplicated in most of the universities. These nine institutions enrolled 15019 students in the year 1997/98 and 18851 students in the year 1998/99, compared to 6035 in 1980/81, 7645 in the year 1985/86, and 11920 in the year 1990/91 (Statistical Reports).

\section{Private universities: a preamble}

The idea of having a private university in a country like Jordan was unthinkable till recently. One major reason for that is the fact that University education, not only in Jordan but in most neighboring countries, is monopolised by the State. Only in a few cases were there some exceptions, the most well-known being the American Universities in Beirut and Cairo. It was necessity that triggered the idea of setting up a private university in the country. It so happened that in 1985 there was a conference for Jordanian expatriates or 'emigrants' who were mostly working in the Arabian Gulf States and one major recommendation of the conference was to petition the Jordanian government for permission to establish a private university in the country. This recommendation was motivated by the fact that children of expatriates could not be admitted into Jordanian 
universities due to a complex quota system which allows only up to $5 \%$ admissions to expatriates. In other words, only $5 \%$ of the seats are allotted to children of Jordanians who live abroad, a percentage which far from satisfies demand. The placement of these students in countries other than Jordan is perceived by parents to be problematic or even seriously dangerous politically, financially, socially and culturally. Such a perception was even more strong with regard to the futures of female offspring. As a result, the expatriate community succeeded in establishing their agenda and carried through their recommendation to found a private university in Jordan which catered for the needs of expatriates in the main. This university was to be a non-profit institution. The Council for Higher Education responded positively to the recommendation of the conference and the establishment of the first private university in the country was 'licensed' in principle. The University was named the Applied Science University and it had to start with a capital of no less than eight million Jordanian Dinars or approximately \$US11.4 million. ${ }^{1}$

TABLE 1: Development and Growth of Jordanian Private Universities

\begin{tabular}{|r|l|c|l|}
\hline No. & Name of Private University & $\begin{array}{l}\text { Date } \\
\text { est. }\end{array}$ & $\begin{array}{l}\text { Started } \\
\text { Teaching }\end{array}$ \\
\hline 1. & Amman Private University & 1989 & $1990 / 91$ \\
2. & Applied Science University & 1989 & $1991 / 92$ \\
3. & Philadelphia Private University & 1989 & $1991 / 92$ \\
4. & Al-Isra Private University & 1989 & $1991 / 92$ \\
5. & * Princess Sumayya College for Technology & 1990 & $1991 / 92$ \\
6. & Jordan University for Women & 1990 & $1991 / 92$ \\
7. & Jordan Academy of Music & 1989 & $1992 / 93$ \\
8. & Jerash Private University & 1991 & $1993 / 94$ \\
9. & * College of Educational Sciences & 1993 & $1993 / 94$ \\
10. & Al-Zaytoonah Jordanian Private University & 1990 & $1993 / 94$ \\
11. & Zarka Private University & 1991 & $1994 / 95$ \\
12. & Irbid National University & 1991 & $1994 / 95$ \\
\hline
\end{tabular}

* All but the two asterisked universities are owned by investing companies which are licensed and supervised by the Ministry of Commerce and Industry. Princess Sumayya College is not so profit-oriented as the other institutions, while the College of Educational Sciences is a non-profit establishment belonging to UNRWA. 


\section{Fast growth: other private universities}

No sooner had the Applied Science University been given a license to operate than other applications began to be submitted to the Council of Higher Education, to the extent that those authors writing about the private higher education sector in Jordan use the word 'overflow' with reference to the sheer number of applications received. It became clear from the very outset that investors were after money, and that the original idea of justifying the setting up of a private university to cater for the sons and daughters of expatriates vanished quickly into thin air. The Council licensed three private community colleges to be turned into full-fledged universities. ${ }^{2}$ Other permits were granted to twelve universities, all but two of which are profit-making establishments. As many and even more applications for licensing are still pending and the Council does not seem to be disposed to grant more permits at present. The following Table shows the development of the establishment of these universities chronologically.

A look at Table 1 clearly shows that over a period of no more than five years, twelve private universities were established. It is also clear that other than Zarka, Irbid and Jerash, the other nine universities are in Amman or in the very vicinity of Amman. The table clearly shows the implied tough competition: a competition for investment.

\section{Growth of student enrollment}

As the Council for Higher Education approved the establishment of private universities, the question directly arose as to who should control, supervise or at least regulate these institutions, and how this was to be done. The first issue that the Ministry of Higher Education had to deal with is whether to allow these universities to exercise an open-door policy of admission or to regulate access in some way or another. The Ministry decided to establish its control by designating the numbers of students that were to be admitted each year and by establishing the minimum average General Secondary School Certificate passes to be accepted. The Law which was decreed in 1989 for private universities regulated admission beside several other aspects of administrative matters. The following Table shows the numbers of students enrolled in private universities compared to those enrolled in Public universities. The figures for Public Universities include those enrolled in graduate studies.

Table 2 clearly shows that the student enrollment in private universities has been on the increase ever since the first university opened in the year 1990/91. It has almost doubled every year in the first four years, and then increased by 20 - 
TABLE 2: Growth of student enrollment in Public and Private Universities

\begin{tabular}{|l|r|r|r|r|r|r|r|r|r|}
\hline Year & $90 / 91$ & $91 / 92$ & $92 / 93$ & $93 / 94$ & $94 / 95$ & $95 / 96$ & $96 / 97$ & $97 / 98$ & $98 / 99$ \\
\hline Public & 36165 & 41517 & 49945 & 49944 & 54437 & 56652 & 58834 & 61257 & 67894 \\
\hline Private & 1324 & 4072 & 7003 & 11319 & 16109 & 24868 & 30583 & 32851 & 35207 \\
\hline
\end{tabular}

$30 \%$ between 1993-1996. Numbers have tended to stabilise over the last three years. The number of students multiplied by almost 25 times between 199/91 and $1997 / 98$. In the first few years, it was only a small fraction compared to enrollment in public universities, but it became close to half of the enrollment in public universities. It should be noted that the figures of enrollment in public universities include all graduate students in these universities. In other words, if graduate students are excluded in order to be in a better position to compare like with like, student enrollment in private universities would amount to more than half the enrollment in public universities. The table also clearly shows that private universities have taken a good share of the load of offering university education to the ever-increasing number of Jordanian high school graduates. The capacity of Jordanian public universities has always fallen short of accepting other than a marginal percentage of high school graduates in the country, utilising a complex system of competitive quotas allocated to different geographical, social and occupational sectors in order to regulate access. ${ }^{3}$

\section{Sources and characteristics}

It is important at this stage to consider the profile of students seeking admission into private universities in Jordan. There are as yet no studies available on the characteristics of these students. Nevertheless, several valid observations can be made:

1. Generally speaking, students who are not admitted to the public universities go to the private universities. This is particularly true of two categories of students:

(a) those whose average in the high school leaving exam falls between 60 and 65 and who therefore cannot, by law, be admitted to public universities but may, by law, be admitted to private universities. Averages less than $60 \%$ are not acceptable in either. This category, I believe, forms a sizable percentage of those admitted. 
(b) those who fail to make it into public universities within the quota established according to competition for places along social, geographical and occupational criteria.

2. A minority of students who have obtained high grades in their examinations, but who nevertheless prefer to go to private universities.

3. Students from other Arab and foreign countries. This category has been on the increase in terms of numbers since 1990/91. The percentages fluctuate because of the increase in enrollment among Jordanians. The numbers - as shown in Table 3 below - grew more than 17 times from 1990/91 till 1998/99

TABLE 3: Private Universities Arab and Foreign Student Population

\begin{tabular}{|l|r|r|r|r|r|}
\hline Nationality & $1990 / 91$ & $92 / 93$ & $94 / 95$ & $96 / 97$ & $98 / 99$ \\
\hline Jordanians & 1006 & 4888 & 11839 & 24929 & 29624 \\
\hline Arab & 318 & 2092 & 4182 & 5415 & 5583 \\
\hline Foreign & - & 23 & 88 & 239 & \\
\hline Total & 1324 & 7003 & 16109 & 30583 & 35207 \\
\hline \% of A\&F & $24 \%$ & $30.2 \%$ & $26.5 \%$ & $18.4 \%$ & $15.8 \%$ \\
\hline
\end{tabular}

It is generally felt that students enrolling in private universities come from families with a higher income, come from families working outside Jordan (mostly in the Gulf) and, more importantly, have lower averages than their peers in public universities.

\section{Faculty members: growth and development}

The following Table shows the growth of the numbers of faculty members in Private universities according to academic rank.

Table 4 shows that the number of faculty members in private universities has been steadily increasing since the opening of the first university in 1990/ 91. The bulk of the faculty members is at the Assistant Professorial level. The Table also shows the percentage of those at the professorial level steadily decreased from $25 \%$ in 1990 to $8 \%$ in $1998 / 99$. The decrease, however, was 
TABLE 4: Growth and distribution of faculty members at private universities according to rank

\begin{tabular}{|l|r|r|r|r|r|}
\hline Ac. Rank & $1990 / 91$ & $92 / 93$ & $94 / 95$ & $96 / 97$ & $98 / 99$ \\
\hline Full Prof. & 11 & 40 & 88 & 117 & 127 \\
\hline Assoc. Prof. & 10 & 61 & 150 & 195 & 227 \\
\hline Assis. Prof. & 17 & 132 & 369 & 597 & 732 \\
\hline Instructor & 6 & 38 & 137 & 231 & 274 \\
\hline Lecturer & - & 82 & 74 & 116 & 61 \\
\hline Teach. Ass. & - & 22 & 98 & 110 & 78 \\
\hline Total & $\mathbf{4 4}$ & $\mathbf{3 7 5}$ & $\mathbf{9 1 6}$ & $\mathbf{1 3 6 6}$ & $\mathbf{1 4 9 9}$ \\
\hline
\end{tabular}

not because their numbers grew less; quite the opposite: their numbers kept growing. Rather, it is because the number of faculty in other ranks increased sharply.

\section{Sources and some characteristics of faculty}

Dahiyyat (1976) - previously a president of a private university, and presently presiding a public university - specified four sources for faculty members for private universities in Jordan:

1. Faculty members from other Arab countries, particularly Iraq, Syria and Egypt.

2. Faculty members who applied for teaching posts at public universities and were not chosen.

3. Faculty members working in public universities but who are either on sabbatical or on leave.

4. Jordanian faculty members who are either retired or occupied key positions in the government and cannot by law be paid a salary in public universities.

These trends reflect rather badly on the standards of education at private universities, as well as on their stability. The following Table sets out the distribution of faculty members in private institutions according to their nationality. 
TABLE 5: Distribution of faculty members according to nationality

\begin{tabular}{|l|r|r|r|r|}
\hline Nationality & $1990 / 91$ & $92 / 93$ & $94 / 95$ & $96 / 97$ \\
\hline Jordanians & 35 & 316 & 655 & 918 \\
\hline Arabs & 9 & 53 & 227 & 411 \\
\hline Non-Arabs & - & 6 & 34 & 37 \\
\hline Total & 44 & 375 & 916 & $\mathbf{1 3 6 6}$ \\
\hline & & & & \\
\hline Total Non-Jo. & 9 & 59 & 261 & 448 \\
\hline \% of Non-Jo. & $25.7 \%$ & $18.6 \%$ & $28.4 \%$ & $32.7 \%$ \\
\hline
\end{tabular}

According to the Statistical Reports published by the Ministry of Education, the number of non-Jordanian faculty members - the overwhelming majority of whom are Arabs - grew from 9 in 1990 to 448 in the year 1996/97. This represents an increase of about 50 times. Of the 448 non-Jordanian faculty members, 37 carry non-Arab nationalities. Out of a total of 1366 faculty member working at the private universities in Jordan, $32.7 \%$ are non-Jordanians, $99 \%$ of whom are Arabs. The overwhelming majority of the Arab faculty members are Iraqis who left Iraq for political and economic reasons after the Gulf War. The return of these faculty members to Iraq once the political situation there changes definitely threatens the stability of these universities. The second major source of faculty members for private universities puts the quality of education in these universities at risk because these members are not as well qualified as one would expect at this level. The majority of these members got their degrees from universities with no special distinction in the ex-Soviet Block, India, Pakistan and other countries. They have never lived regular graduate student university life and they did their research in a hurry at a distance. The third and fourth sources form a minority, but they can be considered as assets to the academic level of these universities.

\section{Administrative and technical staff}

Administrative and technical staff include those who work in the administrative and financial departments of any university. Included also are those in services, maintenance, transportation, gardening, cleaning, and so on. The 
following Table shows the quantitative development of the administrative and technical staff in private universities in Jordan, together with their academic qualifications. Of direct relevance, most likely, would be the ratio of administrators and technicians to students.

TABLE 6: Numbers and quantitative growth of administrative and technical staff and their distribution according to qualifications

\begin{tabular}{|l|r|r|r|r|}
\hline Qualifications & $1990 / 91$ & $92 / 93$ & $94 / 95$ & $96 / 97$ \\
\hline PhD & - & 15 & 58 & 34 \\
\hline MA & 3 & 32 & 36 & 36 \\
\hline H. Diploma & 2 & 11 & 27 & 38 \\
\hline BA & 23 & 222 & 274 & 427 \\
\hline Int. Dip. & 12 & 90 & 220 & 283 \\
\hline Sec. \& below & 17 & 227 & 431 & 729 \\
\hline Total & $\mathbf{5 7}$ & $\mathbf{5 9 7}$ & $\mathbf{1 1 6 4}$ & $\mathbf{1 5 4 7}$ \\
\hline
\end{tabular}

Table 6 shows that there has been a steady and sharp growth of the administrative and technical staff. From the humble figure of 57 in 1990/91 to twenty seven times that number in 1996/97. Those with Intermediate Diploma (i.e. two years after high school) and those with secondary school certificate form the majority of personnel, amounting to about $65.4 \%$ in $1996 / 7$ and $55.9 \%$ in 1994 / 95. Those with an MA and higher form the minority (about $8 \%$ on the average). Those with a BA fluctuated between 38.3 in $1992 / 93$ to $27.1 \%$ in $1996 / 97$. The ratio of administrative and technical staff to students is about 1-20 on the average which is twice the ratio in public universities (1-10).

\section{Fields of specialization: faculties and departments}

It is expected that these private universities offer traditional specialisations that have high market demand (namely courses that are instrumental in getting a job), or focus on offering new specialisations not available in public universities and have high employment market demand. The two universities not owned by companies and that can be considered semi-public, namely Princess Sumayya College of Technology and UNRWA's College of Educational Sciences, do not 
follow the patterns of private universities. Table 7 provides a summary of the fields of study offered by private universities. On can note that these institutions offer a total of 41 areas of specialisation within the faculties of Arts, Education, Science, Economics and Administrative Sciences, Engineering, Law, Shari'a and Agriculture. The overwhelming majority of these specialisations are traditional fields of study already offered by public Jordanian universities. The innovation has been by introducing new major areas of study in some of these universities to respond to needs in the society not met by other universities. These new major areas include Hospital Administration, Hotel Management (offered at the tertiary level by a two-year Hotel Management Institute), Diplomacy in connection with political science (it is also offered as a major area of specialisation in the Institute of Diplomacy in Amman) and Translation at the undergraduate level (translation is offered as a major area in public universities at the graduate level).

\section{Areas of focus}

Other than that, private universities have not contributed to introducing new fields of study. On the other hand, these universities have been keen to offer major areas of study that are in big demand in Jordanian society and in such neighboring countries as Saudi Arabia and the Arabian Gulf States, which constitute the prospective job market for graduates. An analysis of Table 8 shows where the demand is, and shows some major patterns in the selection of an area of specialisation. The following can be concluded.

1. Business Administration, Accounting, and Finance and Banking are major areas that are offered by almost all these universities because they are badly needed, particularly in the private sector. The needs of Jordan and neighbouring countries for specialists in this area is well attested by the high student enrollment in these fields of study, ultimately generating revenue in these profit-making institutions. In the academic year 1997/1998 for example, student enrollment in these major areas of study reached $37.8 \%$, representing the highest percentage of enrollment in all major areas of study in private universities (cf. Ministry of Higher Education, 1998).

2. Computer Studies is offered by almost all universities. It is a relatively new field of study and looks promising in terms of employment opportunities. Figures of student enrollment for the year 1997/1998, for example, show that Computer Sciences attracted the second highest number of students percentage of enrollment according to major area of study. It reached $13.5 \%$, the second after Economics and Administrative Sciences. (Ministry of Higher Education, 1989). 
TABLE 7: Major areas of specialization offered by private universities

\begin{tabular}{|c|c|c|c|c|c|c|c|c|c|c|c|c|c|c|c|}
\hline \multirow[b]{2}{*}{$\frac{\sqrt{0}}{\underline{E}}$} & \multirow[b]{2}{*}{ 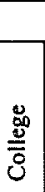 } & \multirow[b]{2}{*}{ 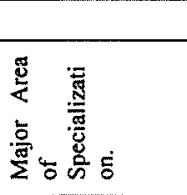 } & \multicolumn{13}{|c|}{ PRIVATE UNIVERSITIES } \\
\hline & & & $\begin{array}{l}\text { 㯊 } \\
\text { है }\end{array}$ & U & & 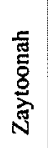 & $\frac{\frac{\pi}{6}}{\frac{1}{2}}$ & 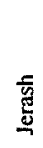 & 总 & 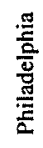 & 离 & $\begin{array}{l}\dot{\bar{s}} \\
\dot{y} \\
\dot{0}\end{array}$ & 胥 & & 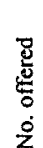 \\
\hline 1. & \multirow{7}{*}{ 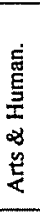 } & Arabic & $x$ & $\bar{x}$ & & $\mathrm{X}$ & & $\mathrm{X}$ & $\mathrm{X}$ & $\mathrm{X}$ & & & $\mathrm{x}$ & & 8 \\
\hline 2. & & English & $\mathrm{X}$ & $\mathrm{X}$ & & $\mathrm{X}$ & $\mathrm{X}$ & $\mathrm{X}$ & $\mathrm{X}$ & $\mathrm{x}$ & & & $\mathrm{X}$ & & 9 \\
\hline 3. & & Translation & & $\bar{X}$ & & $X$ & & & & & & & & & 3 \\
\hline 4. & & Psychology & $\mathrm{X}$ & & & & & & & & & & & & 1 \\
\hline 5. & & Sociology & & $\mathrm{x}$ & & & & & & & & & & & 1 \\
\hline 6. & & History & & & & & & & $\bar{X}$ & & & & & & $\mathrm{l}$ \\
\hline 7. & & Journalism & & & & & & & & & & & & & 1 \\
\hline & \multirow{6}{*}{ 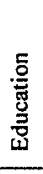 } & & & & & & & & & & & & & & \\
\hline 8. & & Fine Arts, Music & & & & & & & & & & & & $\bar{X}$ & 2 \\
\hline 9. & & Guidance & & $\mathrm{X}$ & & & & & & & & & & & 2 \\
\hline 10 & & Child Educa. & & & & & & & & & & $\mathrm{X}$ & & & 2 \\
\hline 11 & & Subj Teacher. & & & & & & & $\mathrm{X}$ & & & $\mathrm{X}$ & & & 2 \\
\hline 12 & & Class Teacher & & & & & & & $\mathrm{X}$ & & & & & & 1 \\
\hline & & & & & & & & & & & & & & & \\
\hline 13 & \multirow{6}{*}{ 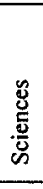 } & Computer Sc. & $\mathrm{X}$ & $\bar{x}$ & & $\mathrm{X}$ & $\mathrm{X}$ & & $\bar{X}$ & $\mathrm{X}$ & $\bar{x}$ & & $\mathrm{x}$ & & 9 \\
\hline 14 & & Informatics & $\mathrm{X}$ & $\mathrm{X}$ & & & & & & & & & & & 2 \\
\hline 15 & & Chemistry & & $\mathrm{X}$ & & & & $\mathrm{X}$ & & & & & & & 3 \\
\hline 16 & & Mathematics & & $\mathrm{X}$ & & $\mathrm{X}$ & & & $\mathrm{X}$ & & & & $\bar{x}$ & & 5 \\
\hline 17 & & Physics & & $\mathrm{X}$ & & & & & & & & & & & 1 \\
\hline 15 & & Biology & & & & & & $\mathrm{X}$ & $\mathrm{X}$ & & & & & & 2 \\
\hline & & & & & & & & & & & & & & & \\
\hline 16 & \multirow{8}{*}{ 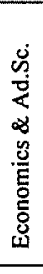 } & Bus. Admin & $\mathrm{X}$ & $\mathrm{X}$ & & $\mathrm{X}$ & $\mathrm{X}$ & $\mathrm{X}$ & $\mathrm{X}$ & $\mathrm{X}$ & & & $\mathrm{X}$ & & 9 \\
\hline 17 & & Accounting & $\mathrm{X}$ & $\bar{x}$ & & $\mathrm{X}$ & $\mathrm{X}$ & $\mathrm{X}$ & $\mathrm{X}$ & $\mathrm{X}$ & & & $\mathrm{X}$ & & 9 \\
\hline 18 & & Finan. \& Bank & $\mathrm{X}$ & $\bar{X}$ & & $\mathrm{X}$ & $\bar{X}$ & & $\mathrm{x}$ & $\mathrm{X}$ & & & & & 7 \\
\hline $\begin{array}{l}19 \\
20\end{array}$ & & $\begin{array}{l}\text { Marketing } \\
\text { Public Admin }\end{array}$ & & $\mathrm{X}$ & & $\mathrm{x}$ & & $\mathrm{X}$ & & & & & & & $\begin{array}{l}2 \\
1\end{array}$ \\
\hline 21 & & Economics & $\mathrm{X}$ & & & & & $\mathrm{X}$ & & & & & $\mathrm{X}$ & & 3 \\
\hline 22 & & Hospital Ad. & $\mathrm{X}$ & & & & & & & & & & & & 1 \\
\hline 23 & & Hotel Admin & & $\bar{x}$ & - & & & & & & & & & & 1 \\
\hline 24 & & Polit.S.\& Dip; & & $\bar{X}$ & & & & & & & & & & & 1 \\
\hline & & & & & & & & & & & & & & & \\
\hline 25 & \multirow{8}{*}{ 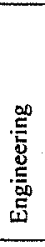 } & Comp Engin. & $\mathrm{X}$ & $\mathrm{X}$ & & & $\mathrm{X}$ & & & & & & & & 3 \\
\hline 26 & & Mechanical & & $\bar{x}$ & & & & & & $\mathrm{X}$ & & & & & 2 \\
\hline 27 & & Industrial & & $\mathrm{X}$ & & & & & & & & & & & 1 \\
\hline 28 & & Chemical & & $\mathrm{x}$ & & & & & & & & & & & 1 \\
\hline 29 & & Civil & & $\bar{x}$ & & & $\mathrm{X}$ & & & & & & & & 2 \\
\hline 30 & & Architecture & & $\mathrm{x}$ & & & $x$ & & & & & & & & 2 \\
\hline 31 & & Com. \& Electr & $\mathrm{X}$ & $\mathrm{X}$ & & & $\mathrm{X}$ & & & & $\mathrm{X}$ & & & & 4 \\
\hline 32 & & Electrical & & & & & & & & $\mathrm{X}$ & & & & & 1 \\
\hline & & & & & & & & & & & & & & & \\
\hline 33 & \multirow{4}{*}{$\begin{array}{l}\dot{v} \\
\dot{Z} \\
\dot{\ddot{Z}}\end{array}$} & Pharmacy & $\mathrm{X}$ & $\mathrm{x}$ & & $\mathrm{X}$ & $\mathrm{X}$ & & & $\mathrm{X}$ & & & & & 6 \\
\hline 34 & & Med Labs & $\mathrm{X}$ & $\mathrm{X}$ & & $\mathrm{X}$ & $\mathrm{X}$ & $\mathrm{X}$ & & & & & & & 6 \\
\hline 35 & & Nursing & & & & $\mathrm{X}$ & & & & & & & & & 1 \\
\hline 36 & & Nutrition & & $\bar{X}$ & & & & & & & & & & & 1 \\
\hline & \multirow{2}{*}{ 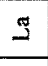 } & & & & & & & & & & & & & & \\
\hline 37 & & Law & & $\mathrm{x}$ & & $\mathrm{X}$ & $\mathrm{X}$ & & $\mathrm{X}$ & $\mathrm{X}$ & & & $x$ & & 6 \\
\hline & \multirow{2}{*}{ 品 } & & & & & & & & & & & & & & \\
\hline 38 & & Islam Shari' & & $\mathrm{X}$ & & & & $\mathrm{X}$ & $\bar{X}$ & & & & $\mathrm{x}$ & & 4 \\
\hline & & & & & & & & & & & & & & & \\
\hline 39 & \multirow{3}{*}{$\stackrel{b}{4}$} & Agr. Econo. & & & & & & $\mathrm{X}$ & & & & & & & 1 \\
\hline 40 & & Animal Prod. & & & & & & $\mathrm{X}$ & & . & & & & & 1 \\
\hline 41 & & Plant Prod. & & & & & & $\mathrm{X}$ & & & & & & & 1 \\
\hline
\end{tabular}


TABLE 8: Distribution of students according to major area of specialization and percentage to total

\begin{tabular}{|c|c|c|c|c|c|c|c|c|c|c|c|}
\hline & \multicolumn{11}{|c|}{ Major a rea of specialization } \\
\hline $\begin{array}{l}\text { Academ } \\
\text { Year } \\
\text { And } \\
\text { Percent. }\end{array}$ & 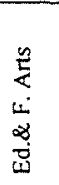 & 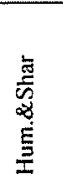 & 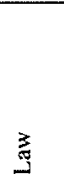 & $\begin{array}{l}\dot{8} \\
\frac{\tilde{g}}{\tilde{D}} \\
\dot{n}\end{array}$ & 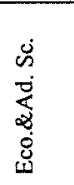 & $\begin{array}{l}\frac{\dot{s}}{\mathrm{n}} \\
\frac{\mathrm{E}}{\mathrm{z}} \\
\mathrm{z}\end{array}$ & 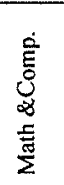 & $\begin{array}{l}\ddot{~} \\
\dot{\tilde{E}} \\
\dot{\Sigma}\end{array}$ & 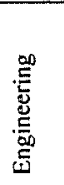 & 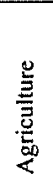 & 嵒 \\
\hline $1996 / 97$ & 1412 & 2950 & 2973 & 421 & 11565 & 245 & 3988 & 3960 & 2288 & 463 & 30583 \\
\hline$\%$ 'tot. & 4.6 & 9.6 & 9.7 & 1.3 & 37.8 & .8 & 13.0 & 12.9 & 7.4 & 1.5 & \\
\hline $1997 / 98$ & 1612 & 3378 & 3202 & 498 & 12444 & 231 & 4440 & 3864 & 2735 & 429 & 32851 \\
\hline$\% /$ Tot. & 4.9 & 10.2 & 9.7 & 1.49 & 37.8 & .7 & 13.5 & 11.7 & 8.3 & 1.3 & \\
\hline $1998 / 99$ & 1749 & 4067 & 3239 & 549 & 13277 & 346 & 5105 & 3691 & 2766 & 409 & 35198 \\
\hline$\% /$ tot. & 4.9 & 11.5 & 9.2 & 1.5 & 37.7 & .98 & 14.5 & 10.4 & 7.8 & 1.1 & \\
\hline
\end{tabular}

3. The third area of emphasis is medical sciences and particularly Pharmacy and Medical Laboratories. This area, according to the same sources, reached $11.6 \%$ of enrollment according to major area, with Pharmacy having the lion's share of $7.7 \%$.

4. The fourth major area of specialization of attraction to enrollment is law. This area attracted 3378 students or $10.2 \%$ of the overall student enrollment in private universities.

5. The least attractive area of study is natural sciences. Natural Sciences attracted no more than 231 students in the year 1997/98. This raises serious questions about the quality of education in the colleges of engineering and medicine in the absence of a well developed college of natural sciences.

\section{Regulation, control, and supervision}

The Jordanian government represented by the Ministry of Higher Education and the powerful higher Education Council felt the need to exercise regulation, control and supervision over private universities. It was realised from the very beginning that these institutions were profit minded and the quest for more money could lead to violations of the tradition of scholarship associated with universities. A temporary law governing the general organisation and administration of these universities was enacted though not strictly enforced.

The Higher Education Council thus determines the number of students to be admitted to each university every year. This is important given that there is always 
a temptation to take more students that one can cope with in order to increase revenue from fees. In another step, the Council has issued detailed criteria specifying the requirements for two kinds of accreditation, 'general' and 'special'. 'General accreditation' lays down requirements in four areas, namely administrative organisation, academic organisation, buildings and facilities, and finally instruments, equipment and general educational resources. To be clearer, general accreditation requires the availability of convenient and well-equipped classrooms, typing, copying, projectors, tape recorders, computers, study halls, laboratories, workshops, a library, a clinic, a cafeteria, sports facilities, and so on. The special accreditation which is intended to accredit different major areas of specialisation offered by private universities.

'Special' and 'specialization' (i.e. major area of study) accreditation stipulates requirements that must be met in four areas, namely

(a) the study plan as to its general structure, distribution of credit hours, number of credit hours for each specialisation and the distribution of courses on the different content areas in the specialisation;

(b) faculty members and technicians as to their numbers, ratio to students, qualifications and experience;

(c) books, references and professional journals as to the number of each that should be available and for each specialisation;

(d) instruments, machines, laboratory equipment, workshops and audio-visual aids.

Whenever a private university is ready for general or special accreditation, it files an application. The Ministry/Council of Higher Education forms a team of specialists to visit the university and evaluate it according to very specific forms prepared beforehand.

Despite these regulatory measures taken by the Ministry, these universities have not quite lived up to expectations. In an interview with a Jordanian paper (Al-Nsour 1996, in Al-Tall 1998), the Minister of Higher Education did not mince words: 'The Ministry has followed up on the mess in student admissions when these universities accepted twice the number of students allowed by the Ministry. The Ministry asked these universities to take corrective measures and we are going to be strict, but without suppression.' The Minister expressed his conviction that supervision should be strictly maintained after the accreditation process, since some universities rented equipment and machines to meet standards, but returned these once the committees of accreditation finished their report. 


\section{Profiting or profiteering}

It is obvious in the financial circles in Jordan that private universities have so far proved to be a great success in terms of turning tidy profits, as can be seen from some of the published budget reports of some of the mother companies owning these universities. Al-Tall (1998) gave one example of the profit-oriented nature of private universities. He depended on what was published in Al-Aswaaq, a Jordanian weekly economic review. The Annual report of the Arab International company for Investment which owns Applied Science University stated that the company has made 4.5 million JDs in profits in 1995 using a capital of 10.125 JDs. Of that amount of profits, 2.65 million were allotted for distribution. The writer maintains that these figures are phenomenal.

It is worth noting in this connection that because of the enormous profits made by private universities, public universities have started programmes admitting lower averages and asking for fees matching those of private universities (in some cases 10 times the regular fees paid by regular students in public universities): These programmes have been called 'Parallel Education Programmes' or 'Programmes of Parallel Studies' and some of the profit public universities make goes to solve the acute financial problems of these institutions. In some public universities, a proportion of the revenue goes to faculty members who teach these programmes as compensation for being overloaded. Public universities which complain from over-crowded conditions do not mind accepting more students if they are willing to pay the designated high fees. A Jordanian student who scores a high average but falls short of getting access to, for instance, the department of computer sciences will have to put up with seeing another Jordanian student with a far lower average gaining access to the department because he can pay the fees of 'Parallel Studies'.

\section{Assets, problems and challenges}

The idea of starting private universities is by itself pioneering in this part of the world. In fact, even before the experience is evaluated, several private universities in other Arab countries have been established along the lines of the Jordanian setup and several others in other Arab countries are being contemplated. In Jordan itself, many applications for licensing new universities are pending the Council of Higher Education's approval.

Private universities in Jordan have indeed solved many problems, most important of which is taking some of the burden off the shoulders of public universities whose admission capacities have always been exceeded to 
accommodate more high school graduates. These universities have also had serious financial problems. Private universities have been placing thousands of high school graduates who would otherwise have either left for another country for their education (spending an estimated 300 million JDS yearly), exercised more pressure to get into public universities, or remained without university education. Responding to the needs of these students could not have come at better time, namely immediately after the Gulf War and the return of hundreds of thousands of Jordanian families from the Gulf. These universities have also been offering education to an increasing number of Arab and foreign students from over forty different countries.

Private education at the university level in Jordan is relatively a big financial investment estimated at 200 million JDs. These universities have offered thousands of jobs for Jordanians, and they are offering more with their expansion.

However, the birth, growth and expansion of these universities have been strewn with problems of all kinds. Taking the right action for each of the big questions raised concerning so many aspects of running and maintaining these private institutions is a big challenge for the future of these universities. The following are some of the major problems/challenges facing private universities.

\section{Standards: balancing profitability and quality}

As shown earlier, the Ministry of Higher Education and the Council of Higher Education have taken measures to ensure that private universities meet the minimum requirements of the accreditation process which is in direct relationship to the quality of education in Jordan. However, no further measures of control over the quality of education are taken other than what these institutions try to offer in this respect. I have not come across any systematic research studies evaluating the standards of the graduates of private universities. However, if we take individual observations, impressions of many educators, experiences of faculty members who spent a sabbatical in these universities and the scanty evaluative remarks of authors on higher education in Jordan, and if we moreover examine the input of these universities, a very dim picture emerges. Sometimes these universities are called 'shops', and 'supermarkets', due to their excessive emphasis on financial gains. People who call these universities these names do imply that the issue of standards is not of primary concern to these institutions. Al-Tall (1998) addresses this issue daringly and with concern when he states: 
'There is a feeling among the students of private universities that the student's mere payment of the high fees makes his graduation almost guaranteed... because these universities are in perpetual need of students. This kind of feeling has been reinforced by the commercial advertisements about some of these universities in the mass media in a way which showed these universities dying to get 'clients' by all means. These universities should have depended on the quality of education offered as a means to show distinction. ... There are cases when shareholders in some of these universities interfered to raise passing percentages and to overlook unexcused absenteeism'. [my translation]

The need for striking a balance between profitability on one hand and quality on the other has been lacking and has to be catered for. Attaining higher standards may require raising the admission scores and risking some of the profits. Al Tall (1998) maintains that standards may be jeopardised even further if the government responds positively to the call of private universities for lowering the admission average down to $50 \%$ in order to attract more students. It is imperative in this connection to state firmly that if the private universities think and plan to get this proposal approved, they can do so. Private universities have a lot of influence; they have a strong lobby and they can buy more influence if need be. They can hire people to get them through and they have done so on more than one occasion. It suffices to state here that private universities hire ex-ministers of Higher education, ex-ministers, ex-public university presidents for their symbolic presidency of their universities. It is also necessary to say that most of these universities are owned by influential people in government and the private sector. The impression of innocent talk about privatisation, democracy, relieving the government of some of its burdens and so on are arguments forwarded by the people who were hired to do the job.

\section{Lack of catering for excellence, research and student and faculty development}

It follows naturally that because of the preoccupation with profit and, as Nsour (1996) put it, 'the temptation of saving more money at the risk of quality', these private universities have never had academic excellence as one of their objectives. These universities either have a minimal or no budget at all to allocate to scientific research. They do not send students on scholarships (a student on scholarship may cost up to a quarter of a million Dinars) and they rarely support their faculty to 
present research findings in conferences and seminars. These universities do not have plans to cater for the outstanding student and the talented.

\section{Duality in administration}

Despite the fact that university administration is spelled out by the law of private universities (Law No. 19 of 1989), these universities have constantly tried to avoid the obligations therein when these regard the power attributed to the academic councils or the president of the university. They prefer instead to resort to the law of companies and corporations reinforced by the Ministry of Commerce and Industry. On the pretext that these universities are private 'economic projects', the 'managerial committee' claims the supremacy of the law governing companies and corporations in running these universities rather than the law of private universities. At all times, there is this 'war' between the representatives of capital on one hand, and the representatives of 'academia' on the other. The winner has always been capital. The duality in administration has always weakened these universities since the university presidents' hands are tied, given that the chief controller in the university is not the president - as is the case in public universities - but the owners of the capital. ${ }^{4}$

\section{Deformation of a concept}

When the proponents of private higher education in Jordan are faced with questions regarding the validity of their profiteering ventures, they always invoke the American higher education example, pointing out that private universities in the USA have better standards than public ones. They refer to such highly esteemed American Universities as Princeton, Harvard and Yale, reminding one and all that these institutions are private ones. What is conveniently forgotten is that these universities are non-profit organisations, that they are extremely well supported by charitable organisations, individuals, companies and corporations, and that they have the funds they need in order to ensure that the quest for academic excellence, creativity, the advancement of human knowledge and the actualisation of human potential is successful. Their admission policies are extremely competitive and stringent. They are the pride of the American system of education. Private universities in Jordan is a mere distortion of this noble ideal.

The concept of a private university on the lines of Princeton and Yale has excellent chances of flourishing in Jordan, in a context of Arab-Islamic culture which glorifies learning and the learned. In this culture, the support for learning 
and the learned comes from the creed and from a very long tradition supporting the quest for knowledge. In that sense, the private university in Jordan is simply antithetical to this culture and tradition.

\section{Conflict with building national character}

If profitability remains a major criteria for these universities, it may prove detrimental when taking the collective formation of the personality of the incoming student from an ideological point of view. If the most important thing in a private university is the payment of fees, the country is putting a large percentage of its student population at stake. Lack of discipline, the lightening of academic requirements, toleration of absenteeism, carelessness in testing, relaxation of seriousness, aversion to hard work, and so on may become a welcome change to attract more students into these institutions.

\section{Suggestions for improvement}

There has been an attempt in this paper to outline the major assets and weaknesses of private and privatised higher education in Jordan. Some of the shortcomings of private higher education are detrimental to the national character and some are fatal to creativity and excellence. However, these are institutions which have invested money, effort and a lot of struggle for power. They have powerful lobbies and they can hire (and have hired) people to buy influence and to shape the decisions of such overpowering institutions as the Council of Higher Education. In short, they are there to stay and the best way to deal with them is to try to improve them. Improving these institutions is good for all the 'stakeholders'. The following is a list of suggestions for improvement, mostly based on the arguments and points presented earlier.

These institutions should, at this juncture in their history, redress the issue of quality because it is pivotal for their long term survival. They should reconsider the following:

1. Their admission policies, in such a way as to improve the quality of intake as much as possible. Accepting a majority of those whose averages in high school is in the low 60s is not going to give an index of quality at any time in the history of these institutions.

2. Accepting the idea of striking a balance between profitability and offering good quality education for the new generations of Jordanian. 
3. Showing a sense of commitment to establish, reinforce and maintain good teaching practices in these universities, even though they might conflict with the interest of some shareholders.

4. Avoiding cheap publicity like advertising in the papers about themselves like any other commodity in the market.

5. Avoiding commercial practices, such as that of cutting costs to raise the profits.

6. Changing the decision-making process by granting enough responsibilities to the university councils and committees. The presence of a very strong Deans' council is a necessity for the proper running of these institutions. The 'council of managers' which has been running these institutions according to the law of companies in the Ministry of Commerce and Industry is no substitute to the Deans' Council.

7. The spirit of a university is research. Private universities in Jordan need to allot funds to research budgets.

8. These universities should have more strict conditions for the recruitment of faculty members. They should not accept mediocre applicants even though they might be easier to mange, manipulate and mould.

9. These universities should have long term plans for securing faculty members. As soon as the Iraqi problem with the Western Powers is solved, the Iraqi faculty members will go back to Iraq in a flux similar to their coming into Jordan. The question as to how they will be replaced remains.

10. Private universities have to start a scholarship programme which is effective and long term, so that bright students are sent abroad to complete their education and go back to teach in these universities.

11. They should have programmes that respond to the creativity of students, encourage it and enrich it.

Muhammad Raji Zughoul is a Professor of English and Applied Linguistics at the Department of English of Yarmouk University, Irbid, Jordan. He obtained his BA and MA from the American University of Beirut and his Ph.D from the University of Texas at Austin. He chaired the Departments of English at Yarmouk, Modern Languages at Yarmouk, Modern Languages at Applied Science University, and Department of English at the College of Basic Education in Kuwait. Professor Zughoul has more than forty papers published in international professional journals. Contact address: Box 4799, Department of English, Yarmouk University, Irbid, Jordan. Tel. 009622-7271100 ext.3259; Fax.: 009622-7241-481. E-mail: murazug@hotmail.com 


\section{Notes}

1 See, for example, Applied Science University: A Proposed Project (Unpublished Manuscript Circulated to all Founders, 1989). According to this document, the objectives of the Applied Science University were perceived to be, in this order: (1) Cultural (Arab-Islamic identity); (2) raising the cultural and thought levels of students; (3) Supporting the civilising aspect of society; and (4) Ensuring social affinity. In no way was profitability even discussed. Or even hinted at.

2 I think that the Council of Higher Education was under the influence of the strong lobbying of the owners of these three private community colleges. It is my personal estimation that these very community colleges turned universities have been behind the 'commercialisation' of private higher education, and indeed have been behind many of the practices of private universities.

3 It has always been a valid question raised at the national level as to why the national educational institutions do not take in all the graduates of high school. It was impossible throughout the years till the country witnessed the establishment of 12 private universities. With more pressure exercised on public universities for admitting more and more students and the availability of so many community colleges, it has become possible for all these institutions to take in up to $98 \%$ of high school graduates. Al-Su'oud (1995), who was the Minister of Higher Education then, gave the following figures of admission Jordanian public universities accepted 11488 students or $36.5 \%$ of Tawjihi graduates

$\begin{array}{lll}\text { Private Universities } & 7734 & 24.6 \% \\ \text { Public Community Colleges } & 6261 & 19.9 \% \\ \text { Private Community Colleges } & 3949 & 12.6 \% \\ \text { Grants and Scholarships } & 1496 & 4.7 \% \\ \text { TOTAL } & \mathbf{3 0 9 2 8} & \mathbf{9 8 . 3 \%}\end{array}$

4 It is a fact that the most influential decision-making body in private universities is the 'managerial committee' or 'the committee of directors'. There are so many anecdotes on how those with money direct those with the mind. The biggest of these universities, which is now practically wholly owned by a semi-illiterate Jordanian who made a fortune working in the Gulf, has been pioneering in this direction. It has always hired Jordanian celebrities to be on the board of trustees and then, when they turn against the conspicuous treachery of 'capital', are unceremoniously replaced.

\section{References}

Abu-Khudayr, B. (1998) 'Quantitative development of private universities in Jordan: problems and indications'. A paper presented at The Conference on the Criteria for Licensing and the Bases for the Evaluation of Higher Educational Institutions in Arab Countries, held in Rabat. (in Arabic)

Al-Nabhan, M. (1996) Quantitative Development of Higher education in Jordan Between 1984-1995. Amman: National Center for Human Development. (in Arabic)

Al-Tall, A. (1998) Higher Education in Jordan Amman: The Committee on the History of Jordan. Aal Al-Bayt Foundation. (in Arabic)

Al-Su'oud, R. (1995) 'The Admission Policies of Jordanian Public Universities.' A paper presented at the Conference on Higher Education in Jordan: Problems and Solutions held in Amman. (in Arabic) 
Al-Tall, S. (1986) Studies In University Education. Amman: Alliwaa Publishing House. (in Arabic)

Dahiyyat, E. (1996) Private Universities in Jordan. Amman. (in Arabic)

Department of Public Relations (1996) Jordan University of Science and Technology: Facts and Figures. Jordan University of Science and Technology

Higher Education Council (1999) A Statistical Summary on Higher Education in Jordan.

Higher Education Council (1999) Major Areas of Specialization at Private Universities. Unpublished Council of Higher Education Document

Ministry of Higher Education (1985) Education During the Reign of Al-Hussayn. Amman: Ministry of Higher Education. (in Arabic)

Ministry of Higher Education $(1987,88,89,1990,91,92,93,94,95,96,97,98)$ The Annual Statistical Report on Higher Education. Amman: Ministry of Higher Education.

Ministry of Higher Education (1989-1998) Statistical Summary on Higher Education in Jordan. Amman: Ministry of Higher Education.

Nsour, A. (1996) 'An Interview.' An interview on issues in higher education given to Al-RA'I Jordanian Daily, July 17 issue.

Obeidat, S. and Al-Rashdaan, A. (1993) Education in Jordan From 1921-1993. Amman: Co-operative Association of Printing Press Workers. (in Arabic). 